\title{
STRUCTURAL OBSERVATIONS AND U-PB MINERAL AGES FROM IGNEOUS ROCKS AT THE ARCHAEAN-PALAEOPROTEROZOIC BOUNDARY IN THE SALAHMI SCHIST BELT, CENTRAL FINLAND: CONSTRAINTS ON TECTONIC EVOLUTION
}

\author{
KIMMO PIETIKÄINEN and MATTI VAASJOKI
}

PIETIKÄINEN, KIMMO and VAASJOKI, MATTI 1999. Structural observations and $\mathrm{U}-\mathrm{Pb}$ mineral ages from igneous rocks at the Archaean-Palaeoproterozoic boundary in the Salahmi Schist Belt, central Finland: constraints on tectonic evolution. Bulletin of the Geological Society of Finland 71, Part 1, 133142.

The study area in Vieremä, central Finland, contains part of Archaean-Palaeoproterozoic boundary. In the east, the area comprises Archaean gneiss and the Salahmi Schist Belt. The rocks of the schist belt are turbiditic metagreywackes, with well-preserved depositional structures, occurring as Proterozoic wedgeshaped blocks, and staurolite schists, the latter representing higher-strained and metamorphosed equivalents of the metagreywackes. In the west of the area there is an Archaean gneiss block, containing strongly elongated structures, and deformed Svecofennian supracrustal rocks, which are cut by deformed granitoids. These are juxtaposed with the schist belt. The boundaries of these tectonometamorphic blocks are narrow, highly strained mylonites and thrust zones. The metamorphic grade of the supracrustal rocks increases from east to west, the increase being stepwise across the mylonitic block boundaries. The rocks are more deformed from east to west with younger structures overprinting. In the staurolite schists of the Salahmi Schist Belt, the most prominent structure is a lineation $\left(\mathrm{L}_{2}\right)$ that overprints the bedding and axial plane foliation. In Sorronmäki quarry, at the western boundary of the schist belt, this Palaeoproterozoic lineation dominates all the structures in tonalite gneiss, which gives a U-Pb age of $2731 \pm 6 \mathrm{Ma}$. Southeast of the quarry, at the same boundary, the Salahmi schists have been overturned towards the northeast, suggesting that the Archaean gneiss at Sorronmäki has been thrust towards the northeast over these rocks. In the western part of the study area, the Leppikangas granodiorite that intrudes the Svecofennian supracrustal rocks gives a U-Pb age of $1891 \pm 6 \mathrm{Ma}$. In the granodiorite, a strong lineation formed by the intersection of two foliations, which may be $\mathrm{L}_{2}$, is associated with thrusting towards the northeast. The monazite age of the Archaean Sorronmäki gneiss is $1817 \pm 3 \mathrm{Ma}$, and the titanite age of the Svecofennian Leppikangas granodiorite, $10 \mathrm{~km}$ southwest of Sorronmäki, is $1824 \pm$ $5 \mathrm{Ma}$. Within the limits of experimental error, these ages are identical and may be associated with a thermal event that accompanied the $\mathrm{D}_{3}$ deformation phase. $D_{3}$ structures fold $D_{2}$ structures in a plastic deformation zone situated between the sample locations. Pegmatitic granite dykes intrude this NW-SE trending zone.

Key words: schist belts, metagraywacke, schists, gneisses, granodiorites, structural analysis, absolute age, U/Pb, Paleoproterozoic, Archean, Vieremä, Finland 
Kimmo Pietikäinen: Geological Survey of Finland, Box 1237, FIN-70211 Kuopio, Finland

E-mail:kimmo.pietikainen@gsf.fi

Matti Vaasjoki: Geological Survey of Finland, Box 96, FIN-02151 Espoo, Finland

\section{INTRODUCTION}

A prominent feature of the Finnish Precambrian in central Finland is the Archaean-Palaeoproterozoic boundary that occurs along the so-called Raahe-Ladoga zone (Korsman 1988). Proterozoic magmatism within the northwestern and central parts of the zone appears to have occurred within a relatively short period, as syn- and post-tectonic igneous rocks give radiometric ages between 1890 Ma and 1875 Ma (Vaasjoki \& Sakko 1988, Kousa et al. 1994). The southeastern part, however, has undergone a high-temperature, low-pressure metamorphic event considerably later, 1830- 1810 Ma ago (Korsman et al. 1984, Vaasjoki \& Sakko 1988).

Within the Raahe-Ladoga zone, the relationship between the Karelian platform intracratonic to craton margin metasediments and the metaturbidites of the Svecofennian Orogen is of particular interest (Laajoki \& Luukas 1988). Because granulite facies metamorphism associated with a migmatizing event in the southeastern part of the RaaheLadoga zone has mostly erased original features, it is better to restrict such studies to the central and northwestern parts of the Archaean-Palaeoproterozoic boundary zone. In this respect, the Salahmi Schist Belt, consisting of tectonically deformed metasedimentary rocks unconformably overlying Archaean basement, is one area in central Finland in which original features are well-preserved (Savolahti 1965, Korkiakoski \& Laajoki 1988). According to Laajoki and Luukas (1988), all Karelian units are present, being overlain by Svecofennian metasediments. Mafic-felsic igneous rocks, which are presumed to be of Palaeoproterozoic age, intrude all the metasedimentary rocks.

\section{GEOLOGICAL SETTING}

The eastern part of the study area, the Salahmi Schist Belt, is a N - S-trending wedge-shaped zone representing the Archaean craton margin (Fig. 1). Its eastern part (2A in Fig. 1) consists of conglomeratic and turbiditic metasediments with well-preserved depositional structures. Isoclinal to tight folds $\left(B_{1}\right)$ with an axial plane foliation $\left(S_{1}\right.$, Fig. 2) fold the sedimentary bedding $\left(S_{0}\right)$. In the northeastern part of the study area, $S_{0}$ and the $B_{1}$ fold axis are both vertical: mylonitic contact between the turbiditic metasediments and the Archaean area in the east suggests that this attitude is the result of later deformation.

The contact between the rocks in subarea 2A, to the east, and the staurolite schists in subarea $2 \mathrm{~A}^{\prime}$, to the west, is unexposed (subareas in Fig. 1). There are only a few tens of metres between exposures in the different subareas closest to each other. The rocks in these are strongly sheared, with a $\mathrm{N}-\mathrm{S}$ trend, suggesting that a tectonic contact occurs between the subareas. The sudden step in metamorphic grade from the chlorite- and quartzbearing metagreywackes in the east (subarea 2A) to the staurolite-almandine schists in the west (subarea 2A') may support this interpretation. The staurolite schists exhibit a range in chemical composition that is similar to that found between the upper and lower parts of a metagreywacke bed occurring in the eastern part of the study area (Table 1).

The staurolite schists have undergone two deformations, yet the primary bedding can still be recognised in places (Fig. 3). The earlier foliation may correspond to the axial plane foliation of the metagreywackes in subarea $2 \mathrm{~A}$, but this cannot be proven. In the northeast of the study area, the younger foliation $\left(\mathrm{S}_{2}\right)$ trends $\mathrm{NE}-\mathrm{SW}$ but in the 


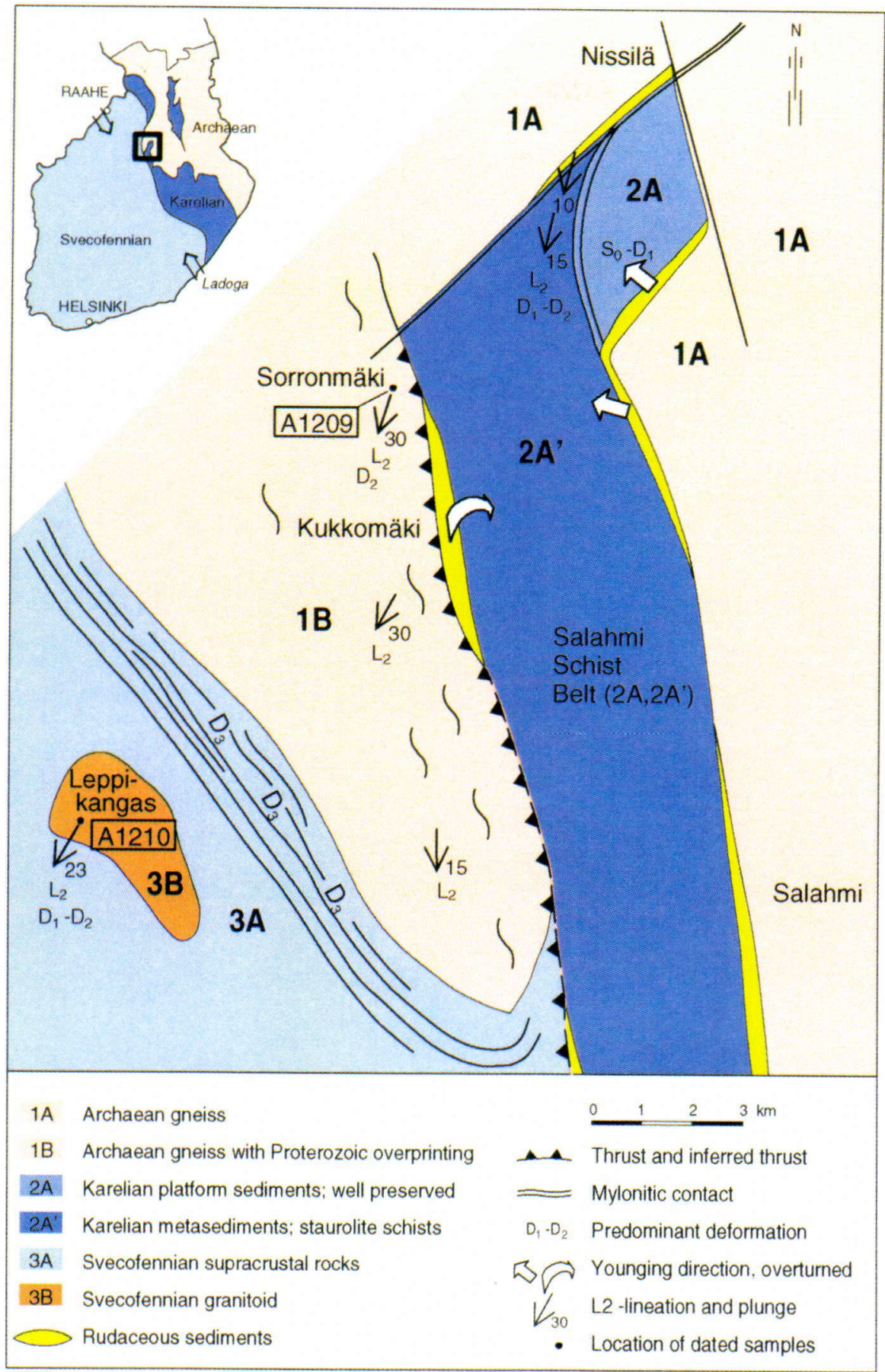

Fig. 1. The study area at the Archaean-Proterozoic boundary in central Finland (insert) consists of subareas: 1) Archaean gneissose rocks with weaker $(A)$ and more prominent Proterozoic overprinting $(B), 2)$ intracratonic to craton margin metasedimentary rocks of the Salahmi Schist Belt with well-preserved primary structures $(A)$ and their more deformed and metamorphosed equivalents, staurolite schists (A'), 3) supracrustal (A) and intrusive (B) rocks of the Svecofennian Orogen. 


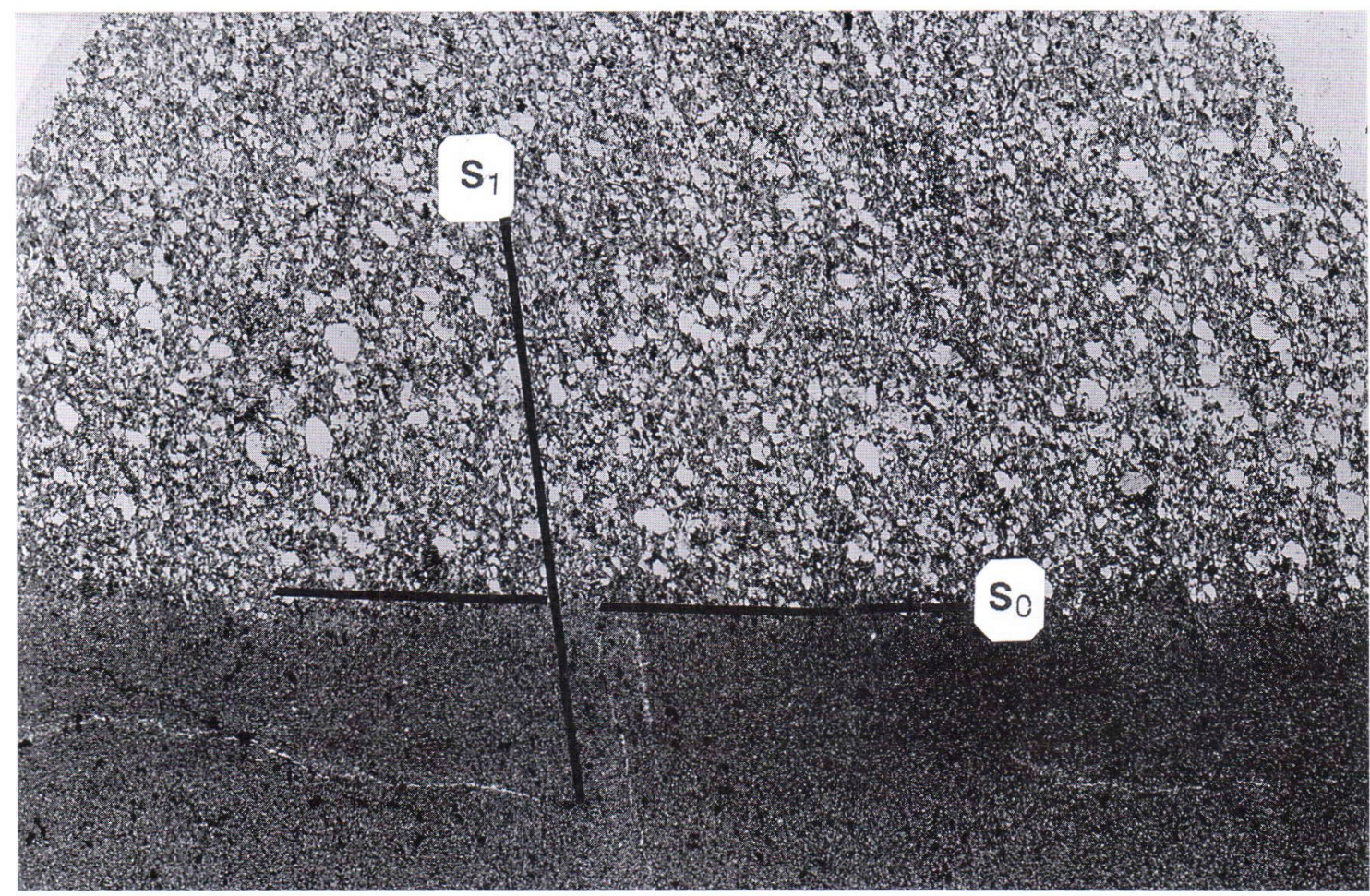

Fig. 2. Microphotograph of part of a well-preserved metagreywacke bed in the eastern part of the study area $\left(2 \mathrm{~A}\right.$ in Fig. 1) showing the bedding $\left(S_{0}\right)$ and axial plane foliation $\left(S_{1}\right)$. The maximum grain size is $0.5 \mathrm{~mm}$ and the grading suggests younging towards the top of the picture. Photo by K. Pietikäinen.

Table 1. Whole rock chemical compositions of metasedimentary rocks from the Salahmi Schist Belt, central Finland.

\begin{tabular}{|c|c|c|c|c|c|c|c|c|c|c|c|}
\hline Sample & $\mathrm{SiO}_{2}$ & $\mathrm{Al}_{2} \mathrm{O}_{3}$ & $\mathrm{Fe}_{2} \mathrm{O}_{3}$ & $\mathrm{MgO}$ & $\mathrm{CaO}$ & $\mathrm{Na}_{2} \mathrm{O}$ & $\mathrm{K}_{2} \mathrm{O}$ & $\mathrm{MnO}$ & $\mathrm{TiO}_{2}$ & $\mathrm{P}_{2} \mathrm{O}_{5}$ & Total \\
\hline KJP-88-14.1 & 64.01 & 17.35 & 7.24 & 2.91 & 0.32 & 1.79 & 3.30 & 0.00 & 0.85 & 0.12 & 97.88 \\
\hline KJP-88-14.2 & 75.04 & 11.11 & 6.51 & 2.83 & 0.24 & 0.80 & 2.36 & 0.00 & 0.57 & 0.11 & 99.57 \\
\hline KJP-88-8.3 & 66.48 & 15.78 & 7.45 & 3.40 & 0.39 & 1.54 & 3.31 & 0.00 & 0.79 & 0.06 & 99.21 \\
\hline R301-5.30 & 74.26 & 11.43 & 6.23 & 2.72 & 0.44 & 1.05 & 1.88 & 0.00 & 0.59 & 0.07 & 98.68 \\
\hline R301-41.60 & 62.24 & 17.23 & 7.76 & 2.93 & 0.82 & 0.80 & 4.40 & 0.19 & 0.67 & 0.10 & 97.14 \\
\hline R302-4.40 & 69.93 & 13.00 & 6.47 & 2.81 & 0.45 & 1.72 & 2.39 & 0.00 & 0.64 & 0.09 & 97.48 \\
\hline R302-95.30 & 62.98 & 16.65 & 7.35 & 2.80 & 0.69 & 0.98 & 3.95 & 0.15 & 0.64 & 0.09 & 96.28 \\
\hline
\end{tabular}

KJP-88-14.1 is from the upper part of the greywacke bed in Fig. 2 and KJP-88-14.2 from the lower part of the same bed. The other samples represent the staurolite-bearing metasediments in subarea $2 \mathrm{~A}^{\prime}$ in $\mathrm{Fig}$. 1 . Total $\mathrm{Fe}$ as $\mathrm{Fe}_{2} \mathrm{O}_{3}$.

west, near the area of gneisses, $\mathrm{S}_{2}$ is NNW - SSEtrending with a shallow or moderate dip WSW. However, further west in the Kukkomäki area (Fig. 1), graded metaconglomerate-arkosite units have been overturned. In the area of staurolite schists and in the area of gneisses (subarea 1B in Fig. 1) to the west, the dominant structure is the
$\mathrm{L}_{2}$ lineation developed on $\mathrm{S}_{2}$. This structure is a mineral lineation plunging gently or moderately $\mathrm{SW}$. In the staurolite schists, about $2 \mathrm{~km}$ west of the eastern contact, $\mathrm{L}_{2}$ is developed as orientated fibrolitic sillimanite, indicating that the sillimanite isograd has been crossed. In tonalitic gneisses at sample location A1209, $\mathrm{L}_{2}$ is visible as strong- 


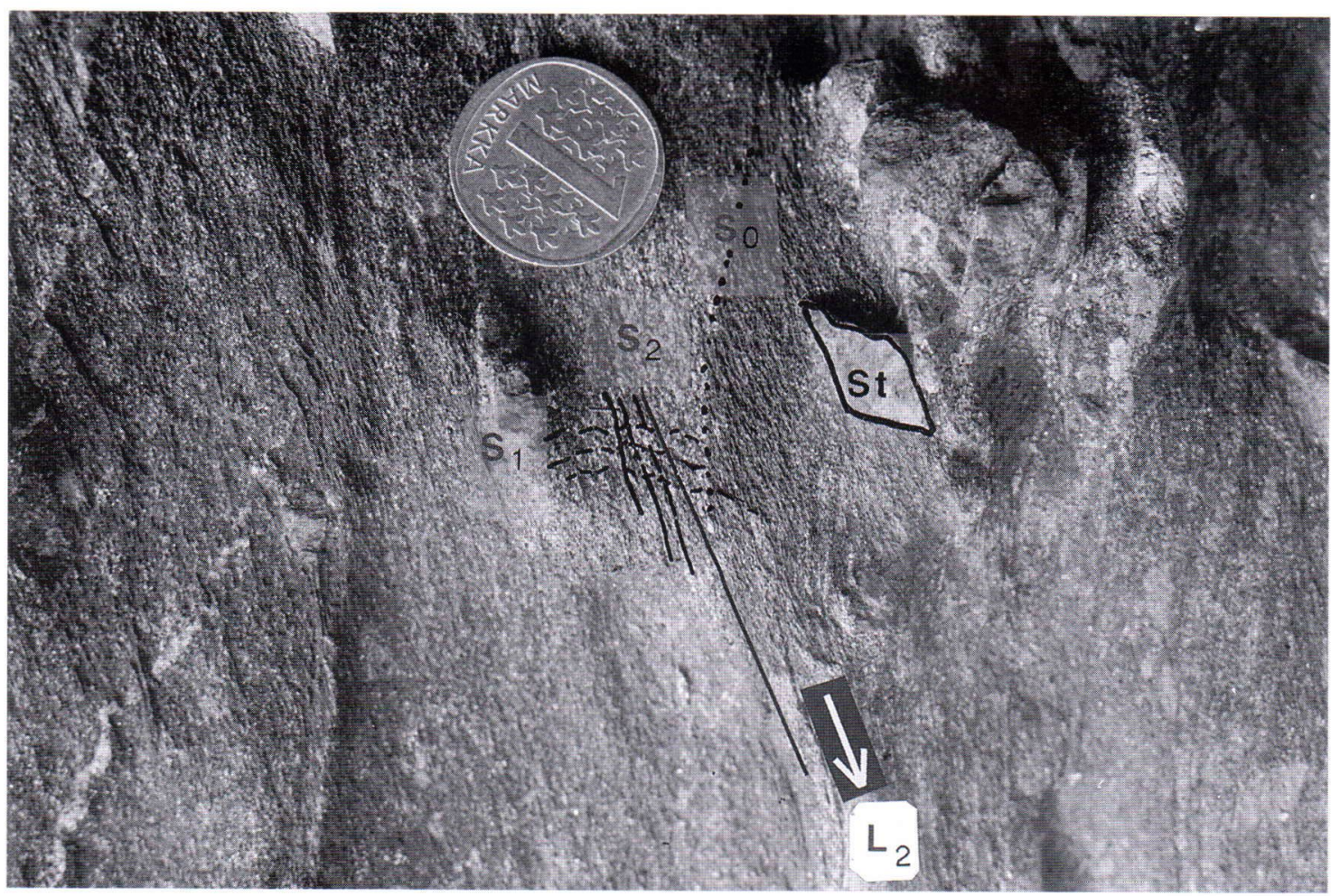

Fig. 3. Staurolite (St) schist at Laajakangas (2A' in Fig. 1) showing the relationship between the most prominent structure, $L_{2}$, with respect to the compositional layering (bedding $S_{0}$ ) and two foliations (weak $S_{1}$ deformed by predominant $S_{2}$ ). The chemical composition of major elements in the staurolite schist falls between the composition of the upper and lower parts of the well-preserved metagreywacke bed in Fig. 2. Diameter of the coin is $24 \mathrm{~mm}$. Photo by K. Pietikäinen.

ly rod-shaped fragments with tonalite gneiss cores surrounded by mantles of sheared biotite (Fig. 4). The tonalitic cores show at least two foliations earlier than " $\mathrm{S}_{2}$ ", suggesting a deformation history longer than that determined from the metasedimentary rocks.

The northern contact of the staurolite schist area is a NE - SW-trending mylonite zone in which the staurolite schists have been normally faulted down dip in relation to the metaconglomerate-covered Archaean rocks in the north. A foliation that cuts both the Archaean tonalites and the metaconglomerates is presumably Palaeoproterozoic, but cannot be demonstrated as either $S_{1}$ or $S_{2}$. Nevertheless, it suggests Palaeoproterozoic overprinting of the Archaean gneisses.
Southwest of the Sorronmäki tonalitic gneisses, the predominant rocks are amphibolites and sillimanite (fibrolite)-garnet gneisses (3A in Fig. 1). These have a gently W- to SW-dipping foliation and SW-plunging lineation, interpreted as $\mathrm{S}_{2}$ and $\mathrm{L}_{2}$, respectively. These rocks are intruded by granodiorites such as the Leppikangas intrusion (3B in Fig. 1), which exhibit two foliations. Their intersection lineation is the most prominent structure in these rocks. Between the Leppikangas granodiorite and the Sorronmäki gneissose tonalites, there is a NNW - SSE-trending zone, in which the gently dipping $\mathrm{D}_{2}$ structures are strongly folded by $B_{3}$. The asymmetry of $B_{3}$ folds suggests an eastern vergence. Pegmatitic granite dykes and strong muscovite alteration in this zone indicate 


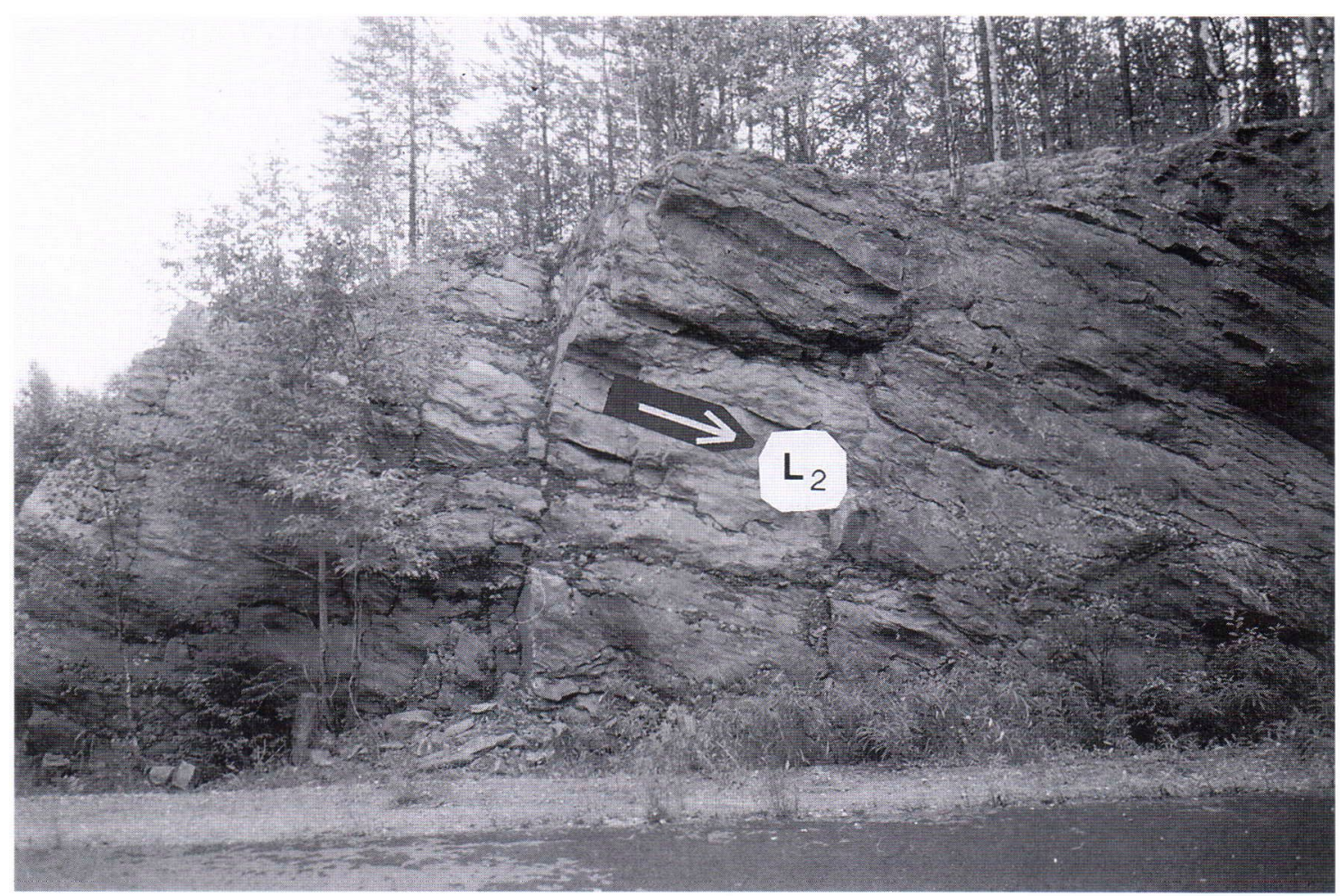

Fig. 4. Strong SW-plunging lineation in the outcrop of dated sample A1209-Sorronmäki. It has been interpreted as the Proterozoic $L_{2}$. The dark colour of the rock is due to biotite mantling the lighter cores of the less deformed quartz-plagioclase gneiss. The picture looks towards the south-southeast. Photo by K. Pietikäinen.

that there were quite high-temperature hydrothermal conditions during the latest $\mathrm{D}_{3}$ deformation phase.

\section{STRUCTURAL INTERPRETATION AND SELECTION OF SPECIMENS FOR AGE DETERMINATION}

In the Palaeoproterozoic metasediments of the Salahmi Schist Belt, the development of two foliations was followed by shearing along the present boundaries of different metamorphic rock areas. The most prominent structural element is the $\mathrm{L}_{2}$ lineation, which plunges gently to moderately SW. The field studies suggest that the same lineation is present in the fragmented tectonic rock unit between the Salahmi schists and the Archae- an rocks north of the schists, and in the Sorronmäki gneisses. The metaconglomerate-arkosite unit at the base of the schists exhibits a normal younging direction at the eastern boundary of the schist belt, whereas these beds have been overturned at the margin with the Sorronmäki gneisses in the west. This structure suggests thrusting of the Sorronmäki gneisses over the Salahmi schists during Palaeoproterozoic $\mathrm{D}_{2}$ deformation. The same deformation has affected the Archaean gneisses north of the Salahmi Schist Belt, but the age of the Sorronmäki gneisses was not known prior to this study. However, the Sorronmäki gneisses are assumed to be older than the Leppikangas granodiorite, because the gneissose banding is cut by $\mathrm{D}_{2}$ structures. The intrusive nature of the Leppikangas granodiorite suggests a Palaeoproterozoic age for its emplacement. 


\section{SAMPLE MATERIAL}

Sample A1209-Sorronmäki (map sheet 332408; national grid coordinates $\mathrm{X}=7088.09, \mathrm{Y}=3488.67$ ) represents a foliated and banded grey tonalite within the Archaean basement. In thin section, its texture is granoblastic. Plagioclase, quartz and biotite are the main minerals of the rock. The unaltered plagioclase is andesine, with a grain size of about $1 \mathrm{~mm}$. Quartz has a bimodal grain size distribution occurring as $1 \mathrm{~mm}$ granoblasts with plagioclase, and as $3 \mathrm{~mm}$ undulose grains enclosing plagioclase and biotite. Brown biotite occurs as single $0.5-1.0 \mathrm{~mm}$ flakes or grain aggregates developed along the major foliation planes. The least deformed domains contain plagioclase and quartz and, less commonly, biotite while the most deformed domains consist almost entirely of biotite. The accessory minerals are apatite, opaque minerals and zircon.

The zircons in sample A1209 are relatively finegrained, about $70 \%$ of them being $<70 \mu \mathrm{m}$ in size. They are light brown, transparent, generally subhedral to euhedral with simple prismatic and pyramidal surfaces. The length/breadth $(\mathrm{L} / \mathrm{B})$ ratio varies from 2 to 4 . No zoning has been observed under oil immersion. Some of the subhedral grains appear to be slightly corroded.

Sample A1210-Leppikangas (map 332407; $\mathrm{X}=7078.66, \mathrm{Y}=3482.00$ ) is from a granodiorite intruding the Palaeoproterozoic metasediments. It is a light grey rock with two foliations and a strong intersection lineation. Plagioclase is the most common mineral, occurring as $3-5 \mathrm{~mm}$ porphyritic but deformed crystals, and as $1 \mathrm{~mm}$ granoblastic grains in the groundmass. Quartz, green amphibole, biotite and potassium feldspar are the other main constituents in the groundmass; biotite generally being an alteration product from amphibole. Epidote, titanite, apatite, opaque minerals and zircon occur as accessory minerals.

The separated zircons of sample A1210 vary from 50 to $200 \mu \mathrm{m}$ in size, and some of the coarser crystals have been broken during milling. They are brown, translucent, euhedral with a simple prismatic-pyramidal habit and have a $\mathrm{L} / \mathrm{B}$ ratio of 2-4. Under oil immersion, they exhibit a dis- tinct oscillatory zoning as typical magmatic zircons.

\section{RESULTS}

The mineral separation techniques, analytical procedures and data treatment methods are those described by Vaasjoki et al. (1991). In addition to four zircon fractions from both samples, monazite from sample A1209-Sorronmäki and titanite from sample A1210-Leppikangas were also analysed. The results are presented in Table 2 and Figs. 5 and 6.

The zircons from sample A1209 exhibit a normal discordancy: the abraded heavy fraction (D) is least discordant and the degree of discordance increases as the density decreases and the uranium content increases. If the most discordant, metamictisised and uranium-rich zircon fraction (C) is excluded from the age calculation, the upper intercept age is $2731 \pm 6 \mathrm{Ma}$ with a Mean Square of Weighted Deviates (MSWD) of 0.06: i.e. practically all of the error arises from analytical procedure only. The monazite is concordant within the limits of experimental error having an age of $1817 \pm 3$ Ma.

The zircons from sample A1210 also exhibit a normal discordancy typical of magmatic zircons. They define a linear trend yielding an upper intercept age of $1891 \pm 6 \mathrm{Ma}$ with a MSWD of 1.3 indicative of almost negligible sample heterogeneity. The titanite is almost concordant having a ${ }^{207} \mathrm{~Pb} /{ }^{206} \mathrm{~Pb}$ age of $1824 \pm 11 \mathrm{Ma}$.

\section{DISCUSSION}

The zircon ages for both the Sorronmäki tonalite gneiss and the Leppikangas granodiorite are those expected, based on their field relationships. The ca. 2730 Ma event is evident throughout the Archaean gneiss terrain in Finland (e.g. Hyppönen 1983, Vaasjoki et al. 1993) and probably represents a period of major crustal accretion. Similarly, ca. $1890 \mathrm{Ma}$ ages for syntectonic granitoids are typical of the Svecofennian orogeny (e.g. Kors- 
Table 2. U-Pb mineral data from the Salahmi area, central Finland.

\begin{tabular}{|c|c|c|c|c|c|c|c|c|c|c|}
\hline \multirow[t]{2}{*}{ Sample } & \multirow[t]{2}{*}{ Fraction } & \multirow{2}{*}{$\begin{array}{l}\text { Uconc } \\
\text { ppm }\end{array}$} & \multirow{2}{*}{$\begin{array}{l}\text { Pbconc } \\
\text { ppm }\end{array}$} & \multirow{2}{*}{$\begin{array}{l}206 / 204 \\
\text { meas. }\end{array}$} & \multirow[t]{2}{*}{$206 / 238$} & \multirow{2}{*}{\multicolumn{2}{|c|}{$\begin{array}{l}207 / 235207 / 206 \\
\text { Corrected for blank }\end{array}$}} & \multicolumn{3}{|c|}{ Apparent age in $\mathrm{Ma}$} \\
\hline & & & & & & & & $6 / 8$ & $7 / 5$ & $7 / 6$ \\
\hline \multicolumn{11}{|c|}{ A1209-Sorronmäki tonalite } \\
\hline A & +4.5 & 138.7 & 61.50 & 8052 & .4144 & 10.253 & .1795 & 2234 & 2457 & 2648 \\
\hline B & $4.3-4.5$ & 176.5 & 71.88 & 7930 & .3803 & 9.200 & .1755 & 2077 & 2358 & 2610 \\
\hline $\mathrm{C}$ & $4.2-4.3$ & 462.3 & 90.80 & 1551 & .1815 & 3.864 & .1544 & 1075 & 1606 & 2395 \\
\hline $\mathrm{D}$ & $+4.5 / \mathrm{abr}$ & 124.4 & 63.39 & 5167 & .4703 & 11.967 & .1846 & 2484 & 2601 & 2694 \\
\hline M & Monazite & 774.5 & 606.18 & 6802 & .3271 & 5.010 & .1111 & 1824 & 1821 & 1817 \\
\hline \multicolumn{11}{|c|}{ A1210-Leppikangas granodiorite } \\
\hline A & +4.5 & 343.4 & 112.14 & 19548 & .3215 & 5.102 & .1151 & 1797 & 1836 & 1881 \\
\hline B & $4.3-4.5$ & 421.1 & 133.64 & 18386 & .3137 & 4.970 & .1149 & 1758 & 1814 & 1878 \\
\hline $\mathrm{C}$ & $4.2-4.3$ & 606.1 & 180.55 & 15450 & .2943 & 4.644 & .1145 & 1662 & 1757 & 1871 \\
\hline $\mathrm{D}$ & $4.0-4.2$ & 737.9 & 210.35 & 6789 & .2807 & 4.398 & .1136 & 1595 & 1711 & 1858 \\
\hline $\mathrm{T}$ & Titanite & 166.3 & 58.82 & 1079 & .3237 & 4.977 & .1115 & 1807 & 1815 & 1824 \\
\hline
\end{tabular}

Common lead corrections:

A1209 zircons: ${ }^{206} \mathrm{~Pb} /{ }^{204} \mathrm{~Pb}: 13.4 ;{ }^{207} \mathrm{~Pb} /{ }^{204} \mathrm{~Pb}: 14.6 ;{ }^{208} \mathrm{~Pb} /{ }^{204} \mathrm{~Pb}: 33.2$

A1210 and A1209 monazite: ${ }^{206} \mathrm{~Pb} /{ }^{204} \mathrm{~Pb}: 15.7 ;{ }^{207} \mathrm{~Pb} /{ }^{204} \mathrm{~Pb}: 15.3 ;{ }^{208} \mathrm{~Pb} /{ }^{204} \mathrm{~Pb}: 35.2$

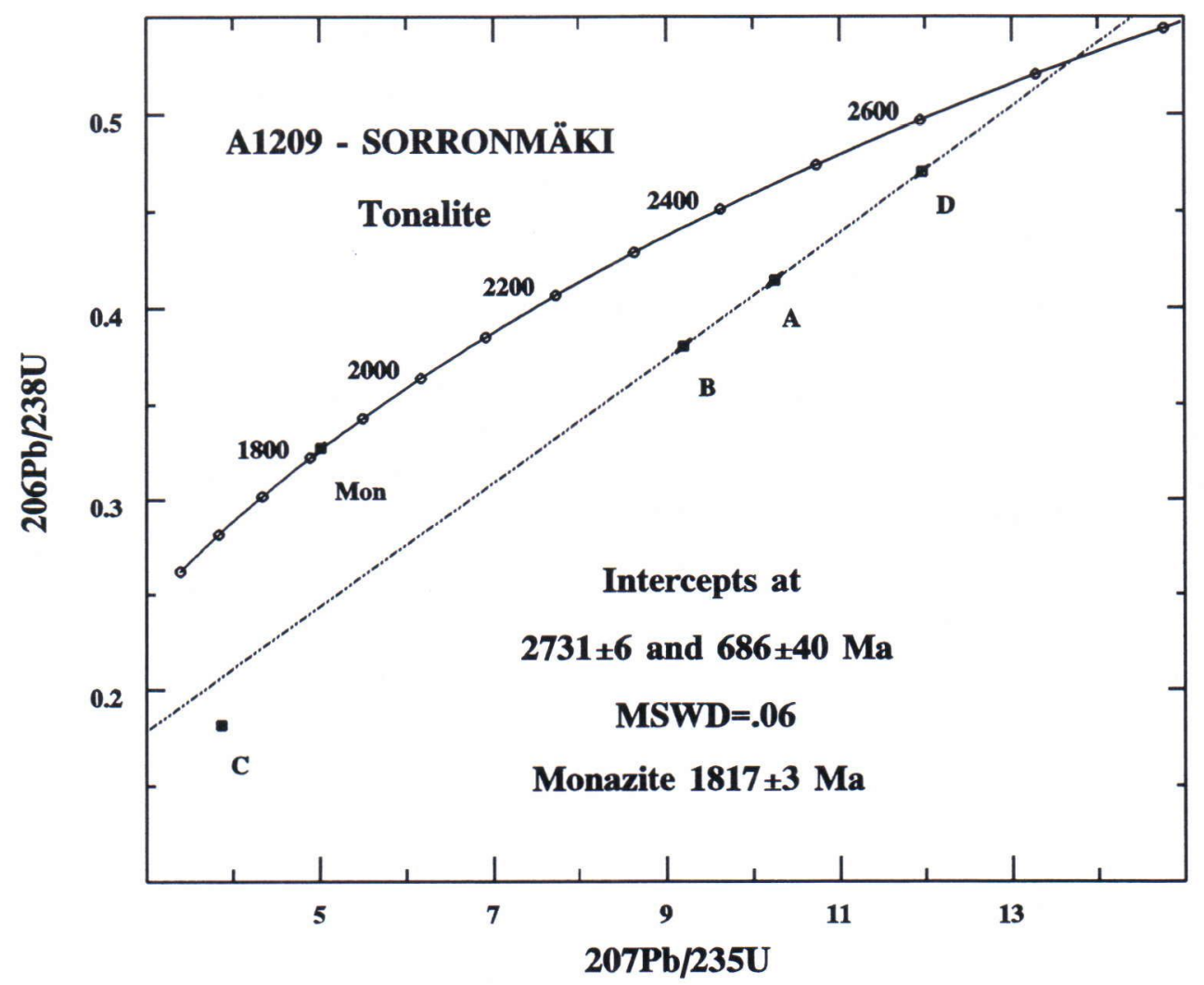

Fig. 5. Concordia plot of U-Pb zircon and monazite data for the Archaean tonalite gneiss at Sorronmäki, Vieremä. Data from Table 2. The most discordant, metamictisised zircon fraction $(C)$ is excluded from the age calculation. 


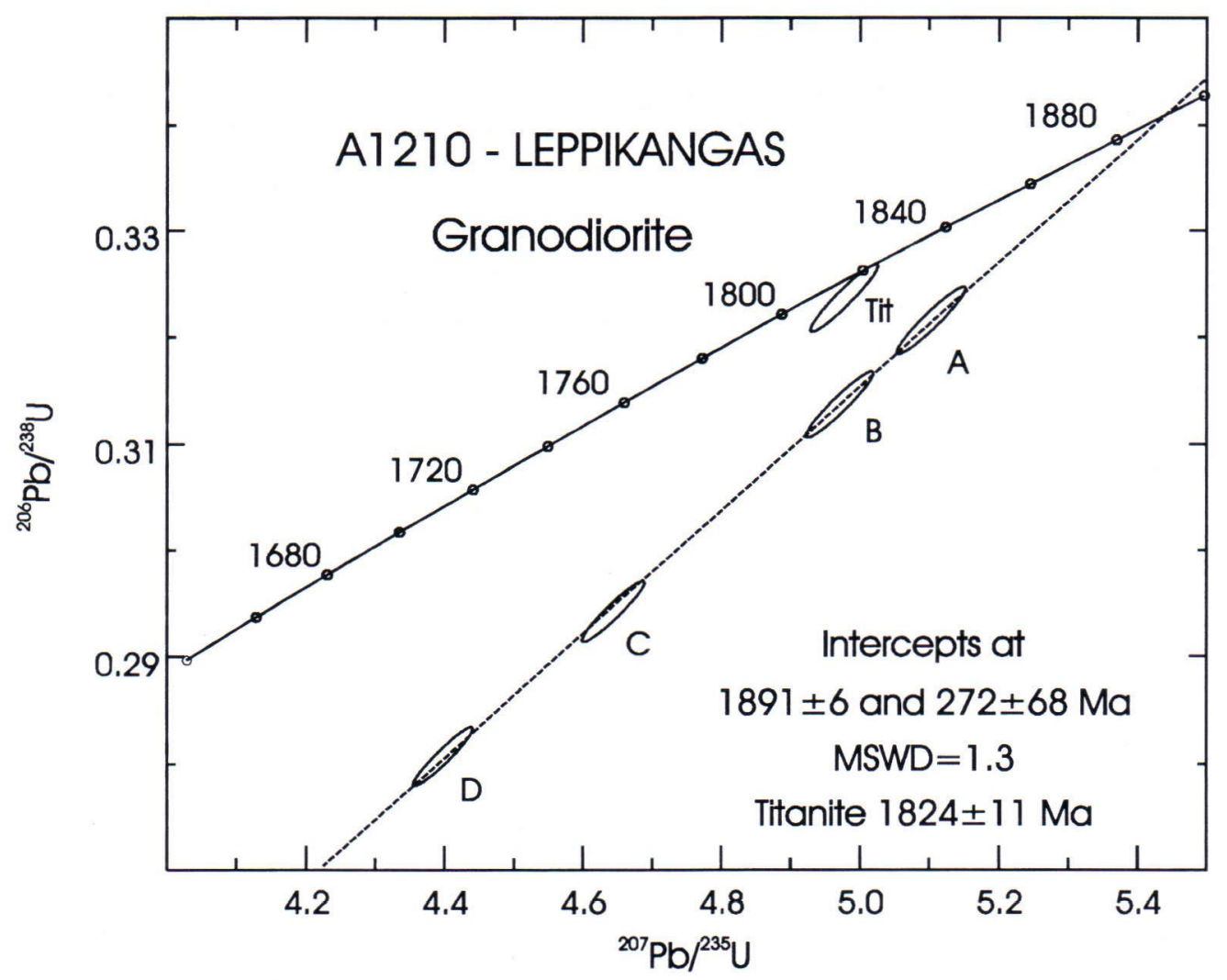

Fig. 6. Concordia plot of $U-P b$ zircon and titanite data for the Svecofennian Leppikangas granodiorite, Vieremä. Data from Table 2.

man et al. 1984, Huhma 1986, Vaasjoki \& Sakko 1988) and, based on $\varepsilon_{\mathrm{Nd}}$ data, the rocks appear to mostly derive from mantle material (Huhma 1986). Tectonically, these rocks seem to predate the regional $\mathrm{D}_{2}$ deformation (e.g. Korsman 1988).

The monazite age of the Sorronmäki tonalite gneiss, $1817 \pm 3 \mathrm{Ma}$, and the titanite age of the Leppikangas granodiorite, $1824 \pm 11 \mathrm{Ma}$, are identical within the limits of experimental error. The combined result, ca. $1820 \mathrm{Ma}$, either represents a slow cooling history of the area or, more probably, is associated with a late thermal event. Such an event may be the $\mathrm{D}_{3}$ deformation phase that is demonstrated by the folding of $\mathrm{D}_{2}$ structures and the injection of granitic material along a NW - SEtrending zone between the two sampling locations. An interesting aspect, of possible regional importance, is that the post- $\mathrm{D}_{3}$ Pirilä granite in the Ran-
tasalmi-Sulkava area, in the southeastern part of the Raahe-Ladoga zone, registers a U-Pb zircon age of 1815 \pm 7 Ma (Vaasjoki \& Sakko 1988).

Based on the structural evidence and $\mathrm{U}-\mathrm{Pb}$ ages from zircon, monazite and titanite, we suggest that during the Svecofennian orogeny, after intrusion of the Leppikangas granodiorite about $1890 \mathrm{Ma}$ ago, the Svecofennian rocks and associated Archaean gneisses, such as the Sorronmäki $2731 \mathrm{Ma}$ old tonalitic gneiss, were thrust northeast over Archaean rocks covered by intracratonic to craton margin metasedimentary rocks. This suture zone was reactivated about $1820 \mathrm{Ma}$ ago, at the same time as migmatisation occurred further southeast in the Raahe-Ladoga zone. Faulting followed these events forming the present mosaic of mylonite-bounded blocks of varying lithology or metamorphic grade. 
ACKNOWLEDGEMENTS. The authors are indebted to Dr Kalevi Korsman, Geological Survey of Finland, for discussions, constructive criticism and initial guidance in the field. Mr Jukka Eskelinen and the technical staff of the Unit for Isotope Geology, Geological Survey of Finland gave valuable assistance in sample collection, mineral separation and mass-spectrometer maintenance. We express thanks to Ms Helinä Moberg, for assisting in preparing Fig. 1, and to the staff of the Kuopio office of the Geological Survey of Finland for help at various stages of this study. We also thank Mr Graeme Waller whose contribution improved both the linguistic and scientific content of this paper.

\section{REFERENCES}

Huhma, H. 1986. Sm-Nd, U-Pb and $\mathrm{Pb}-\mathrm{Pb}$ isotopic evidence for the origin of the early Proterozoic Svecokarelian crust in Finland. Geological Survey of Finland, Bulletin $337.48 \mathrm{p}$.

Hyppönen, V. 1983. Ontojoen, Hiisijärven ja Kuhmon kartta-alueiden kallioperä. Summary: Pre-Quaternary rocks of the Ontojoki, Hiisijärvi and Kuhmo map sheet areas. Geological map of Finland 1:100 000. Explanation to the maps of pre-Quaternary rocks, Sheets 4411, 4412 and 4413. Geological Survey of Finland. 60 p.

Korkiakoski, E.A. \& Laajoki, K. 1988. The Palaeosedimen- tology of the early Proterozoic Salahmi Schist Belt, central Finland. Geological Survey of Finland, Special Paper 5, 49-73.

Korsman, K. (ed.) 1988. Tectono-metamorphic evolution of the Raahe-Ladoga zone. Geological Survey of Finland, Bulletin 343. 96 p.

Korsman, K., Hölttä, P., Hautala, T. \& Wasenius, P. 1984. Metamorphism as an indicator of evolution and structure of the crust in eastern Finland. Geological Survey of Finland, Bulletin 328.40 p.

Kousa, J., Marttila, E. \& Vaasjoki, M. 1994. Petrology, geochemistry and dating of Palaeoproterozoic metavolcanic rocks in the Pyhäjärvi area, central Finland. Geological Survey of Finland, Special Paper 19, 7-27.

Laajoki, K. \& Luukas, J. 1988. Early Proterozoic stratigraphy of the Salahmi-Pyhäntä area, central Finland, with an emphasis on applying the principles of lithodemic stratigraphy to a complexly deformed and metamorphosed bedrock. Bulletin of the Geological Society of Finland 60, 79-106.

Savolahti, A. 1965. On the schists and associated intrusive rocks of the Vieremä-Kiuruvesi region. Bulletin de la Commission géologique de Finlande 218, 1-83.

Vaasjoki, M. \& Sakko, M. 1988. The evolution of the Raahe-Ladoga zone in Finland: isotopic constraints. Geological Survey of Finland, Bulletin 343, 7-32.

Vaasjoki, M., Rämö, O.T. \& Sakko, M. 1991. New U-Pb ages from the Wiborg rapakivi area: constraints on the temporal evolution of the rapakivi granite-anorthositediabase dyke association of southeastern Finland. Precambrian Research 51, 227-243.

Vaasjoki, M., Sorjonen-Ward, P. \& Lavikainen, S. 1993. $\mathrm{U}-\mathrm{Pb}$ age determinations and sulfide $\mathrm{Pb}-\mathrm{Pb}$ characteristics from the late Archean Hattu schist belt, Ilomantsi, eastern Finland. Geological Survey of Finland, Special Paper 17, 103-131. 